Proc. Estonian Acad. Sci. Geol., 1994, 43, 2, 57-68

\title{
SUBDIVISION OF THE ARUKULA STAGE ON THE BASIS OF LITHOLOGICAL AND MINERALOGICAL CRITERIA
}

\author{
Anne KLEESMENT
}

Eesti Teaduste Akadeemia Geoloogia Instituut (Institute of Geology, Estonian Academy of Sciences), Estonia pst. 7, EE-0100 Tallinn, Eesti (Estonia)

Presented by D. Kaljo

Received August 13, 1993; accepted December 8, 1993

Abstract. In the Baltic Region the Aruküla Stage (Eifelian) is characterized by reddish brown cross-bedded sandstone interbedded with siltstone, clay, and domerite. In Estonia it is represented in excellent fossil-bearing outcrops and in a number of borings. The thickness varies from 62.5 to $90 \mathrm{~m}$. In 1981 the Aruküla Stage was divided into two members. More recent and revised earlier lithological and mineralogical data have permitted to distinguish three cycles. These cycles are observable in all sections of the Baltic and Leningrad District, corresponding thus to evolutionary stages of the area and serving as a basis for the distinction of three beds in the Aruküla Stage Viljandi (the lowest), Kureküla (the middle), and Tarvastu (the uppermost one). Lithological and mineralogical criteria have been established to discriminate these beds.

Key words: Devon, stratigraphy, lithology, mineralogy, heavy transparent allothigenic minerals.

\section{INTRODUCTION}

In the East Baltic, Belarus, and northwestern Russia the youngest stratigraphical level of the middle Devonian Eifelian Stage is represented by the Aruküla Stage (Fig. 1). Its coeval analogues are known from wide areas of the East-European Platform. This level was first distinguished as an independent stratigraphic unit by Gross in 1940 (Gross, $1940,1942)$. In the rank of a regional stage, however, it was established by Mark-Kurik in 1958 (Марк, 1958). The first accepted detailed subdivision of this unit into upper and lower parts was given by Viiding in 1981 (Вийдинг et al., 1981; see Table 1). The revision of the plentiful material available at the present time has allowed to define in the section of this stage three levels, which correlate on the whole territory of the East Baltic and northwestern Russia (Fig. 2; Table 1).

\section{GEOLOGICAL SETTING}

The northern boundary of the Aruküla Stage runs from the northernmost tip of the Kura Peninsula up to the northern coast of Lake Peipsi (Fig. 1). The outcrop area forms a $17-55 \mathrm{~km}$ wide belt, most of which lies on the territory of Estonia. The main outcrops representing this stage are also located in Estonia, among them the stratotype, a section 
by a Tartu cemetery situated near the Aruküla caves on the northern boundary of Tartu. The Aruküla caves as well as the outcrops of Tamme on the eastern shore of Lake Võrtsjärv, Kallaste on the western shore of Lake Peipsi, Oisu in the western part of the distribution area of the stage, and Haaslava near Tartu are famous for Devonian fish finds. The rich material collected there during more than 100 years contains the majority of the fauna characterizing this level on the whole EastEuropean Platform. Numerous boreholes penetrating the Aruküla Stage

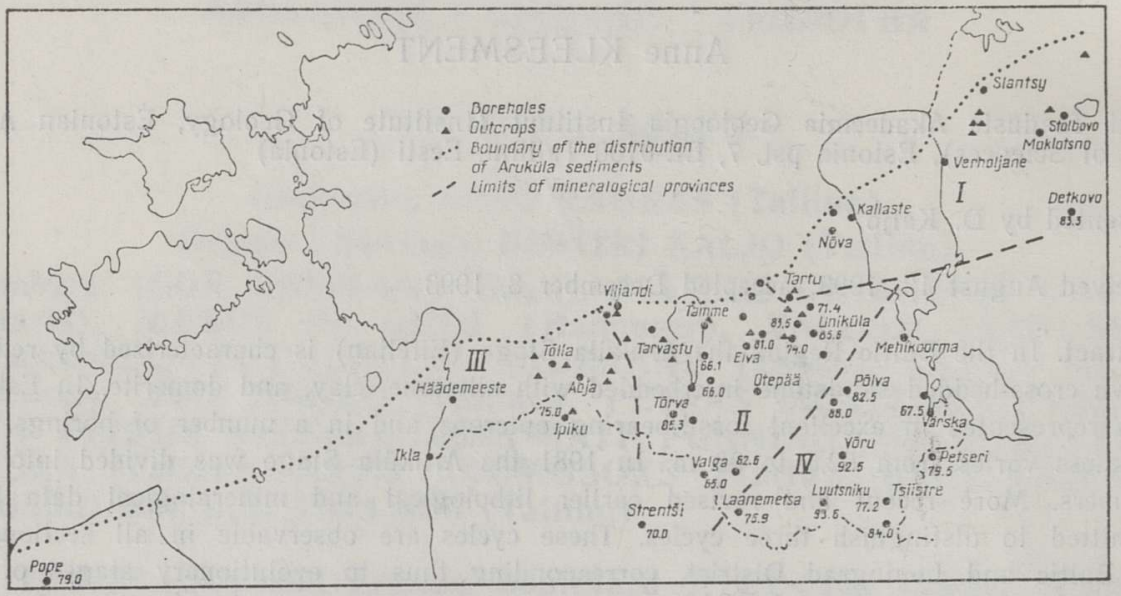

Fig. 1. Map showing the location of the studied sections and the distribution of the mineralogical provinces. Numbers by the boreholes show the total thickness of the Aruküla Stage in metres.

Table 1

History of the stratigraphic definition of the Aruküla Stage

\begin{tabular}{|c|c|c|c|c|c|c|c|}
\hline $\begin{array}{c}\text { Gross, } \\
1940\end{array}$ & $\begin{array}{c}\text { Gross, } \\
1942\end{array}$ & $\begin{array}{l}\text { Orviku, } \\
1946\end{array}$ & $\begin{array}{l}\text { Марк, } \\
1958\end{array}$ & & $\begin{array}{l}\text { Вийдинг } \\
\text { et al., } 1981\end{array}$ & & Present paper \\
\hline $\begin{array}{l}\text { Upper } \\
\text { Heterostius } \\
\text { Zone }\end{array}$ & $\begin{array}{l}\text { Pycnosteus } \\
\text { tuberculatus } \\
\text { Zone }\end{array}$ & \multirow{4}{*}{$\begin{array}{l}\text { Tartu } \\
\text { Stage }\end{array}$} & $\begin{array}{l}\text { Burtnieki } \\
\text { Stage }\end{array}$ & & $\begin{array}{l}\text { Burtnieki } \\
\text { Stage }\end{array}$ & & $\begin{array}{l}\text { Burtnieki } \\
\text { Stage }\end{array}$ \\
\hline \multirow{3}{*}{$\begin{array}{l}\text { Lower } \\
\text { Heterostius } \\
\text { Zone }\end{array}$} & \multirow{3}{*}{$\begin{array}{l}\text { Pycnosteus } \\
\text { palaeformis } \\
\text { Zone }\end{array}$} & & \multirow{3}{*}{$\begin{array}{l}\text { Aruküla } \\
\text { Stage }\end{array}$} & \multirow{3}{*}{ 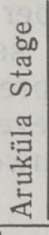 } & Mõra & \multirow{3}{*}{ 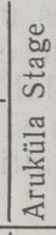 } & Tarvastu Beds \\
\hline & & & & & Member & & Kureküla Beds \\
\hline & & & & & $\begin{array}{l}\text { Viljandi } \\
\text { Member }\end{array}$ & & Viljandi Beds \\
\hline \multirow[t]{3}{*}{$\begin{array}{l}\text { Pterichthys } \\
\text { Zone }\end{array}$} & \multirow[t]{3}{*}{$\begin{array}{l}\text { Pterichthys } \\
\text { concatenatus } \\
\text { Zone }\end{array}$} & \multirow[t]{3}{*}{$\begin{array}{l}\text { Narva } \\
\text { River } \\
\text { Stage }\end{array}$} & \multirow[t]{3}{*}{$\begin{array}{l}\text { Narva } \\
\text { Stage }\end{array}$} & \multirow{3}{*}{ 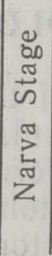 } & $\begin{array}{l}\text { Gorodenka } \\
\text { Sub- } \\
\text { formation }\end{array}$ & \multirow{3}{*}{ 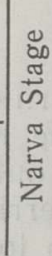 } & $\begin{array}{l}\text { Kernavė } \\
\text { Substage }\end{array}$ \\
\hline & & & & & $\begin{array}{l}\text { Kuningaküla } \\
\text { Sub- }\end{array}$ & & Leivu Substage \\
\hline & & & & & formation & & Vadja Substage \\
\hline
\end{tabular}


have been drilled on the Estonian territory in the course of mapping that started in 1958. The data obtained from these cores together with the outcrop material serve as a basis for a thorough description and detailed subdivision of the stage.

The Aruküla Stage is mainly characterized by red, weakly cemented very fine (mostly $0.1-0.05 \mathrm{~mm}$ ) or fine (mostly $0.25-0.1 \mathrm{~mm}$ ) horizontally and cross-bedded sandstone containing silty, clayey, in the lower part also domeritic interlayers. The total thickness of the stage in Estonia ranges from 62.5 to $92.5 \mathrm{~m}$, decreasing to the southwest as in the whole East Baltic area.
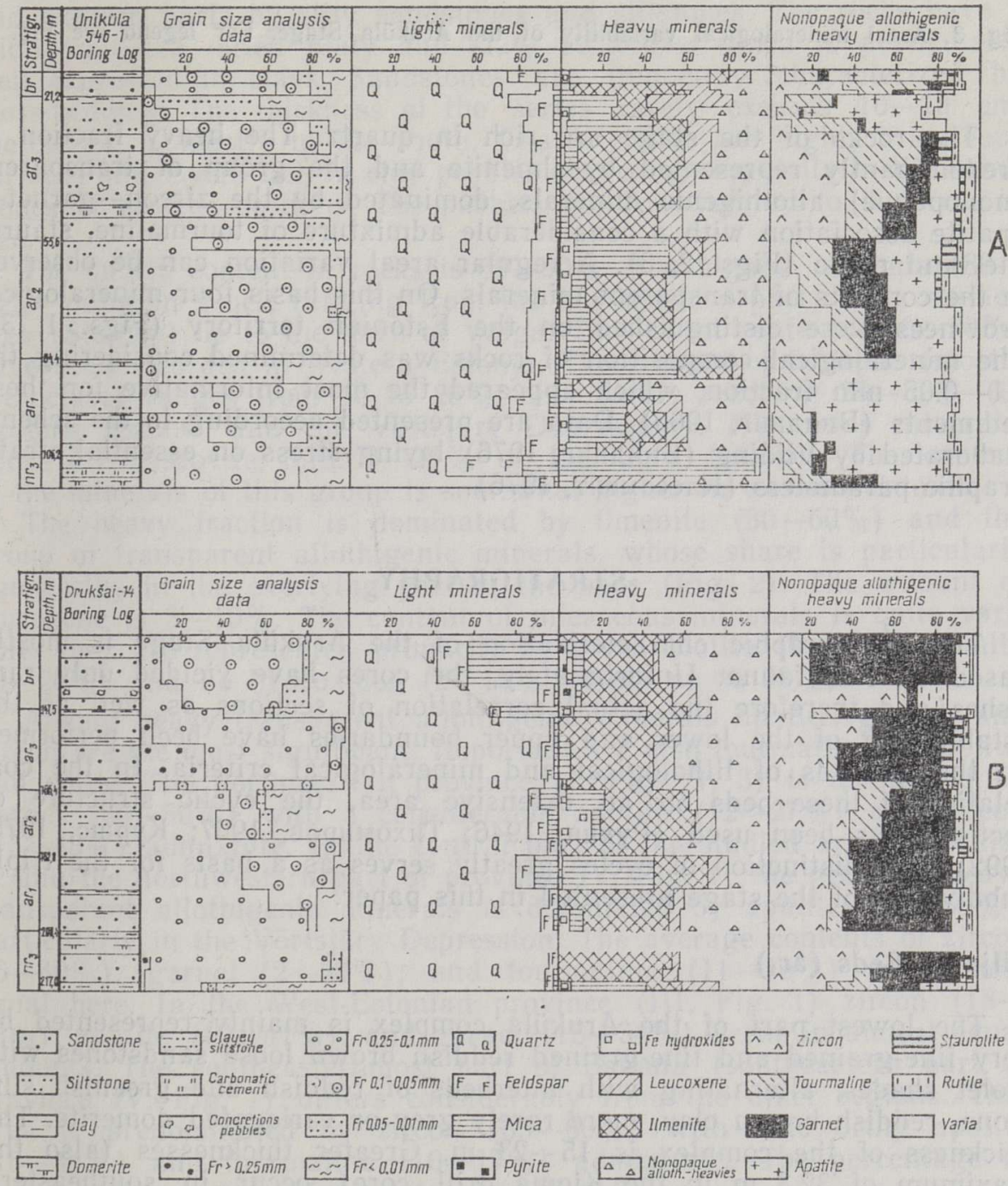

Fig. 2. Granulometric and mineralogical data on the Aruküla Stage in Uniküla, Estonia $(A)$, and Drukšai, northeastern Lithuania $(B)$, core sections.

The initial data on the Uniküla core section were taken from the 1981 annual report of the hydrogeology group of the Geological Survey compiled by O. Gromov, R. Grünberg, K. Kajak, H. Kajak, and V. Tassa. 


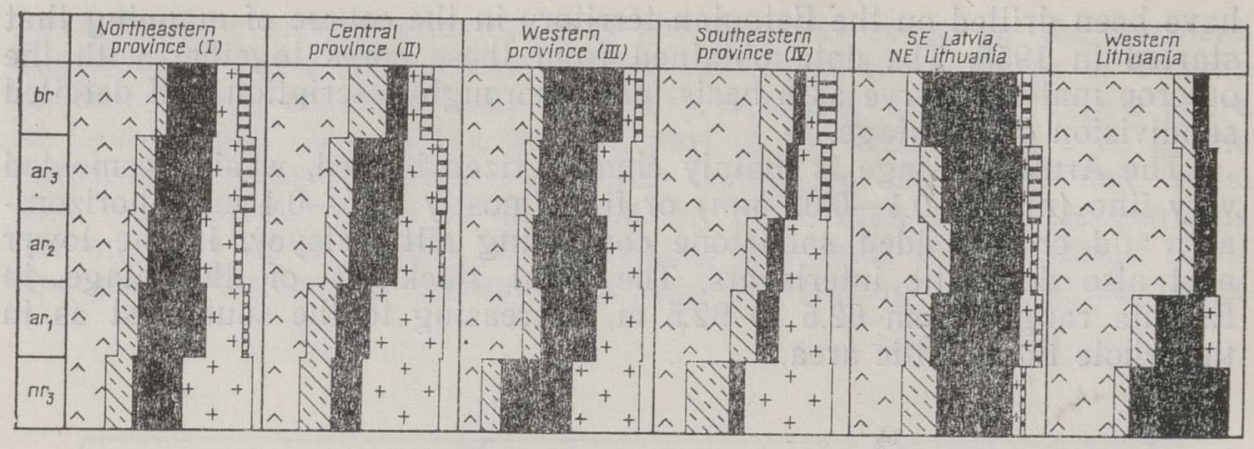

Fig. 3. Areal mineralogical variability of the Aruküla Stage. For legend see Fig. 2.

The rocks of the stage are rich in quartz. The heavy fraction is predominantly represented by ilmenite and the group of transparent (nonopaque) allothigenic minerals, dominated by the zircon-garnetapatite association with a considerable admixture of tourmaline, staurolite, and rutile (Figs. 2, 3). A regular areal variation can be observed in the contents of transparent minerals. On this basis four mineralogical provinces were distinguished on the Estonian territory (Figs. 1, 3). The mineralogical composition of rocks was determined considering the $0.1-0.05 \mathrm{~mm}$ fraction, which appeared the most informative for these sediments (Вийдинг, 1965). Data are presented according to the scheme elaborated by Viiding (Вийдинг, 1976) laying stress on essential stratigraphic parameters (Клеесмент, 1976).

\section{STRATIGRAPHY}

The stratigraphic characterization of the Aruküla Stage is mostly based on fish fauna. Unfortunately, the cores have yielded only rare fishes and therefore the actual correlation of sections as well as the establishing of the lower and upper boundaries have been performed on the grounds of lithological and mineralogical criteria. In the correlation of these beds on an extensive area, the cyclic structure of sections has been used (Рухин, 1946; Тихомиров, 1967; Куршс, 1975, 1992). The distinction of cycles greatly serves as a basis for the triple subdivision of the stage presented in this paper.

\section{Viljandi Beds $\left(\operatorname{ar}_{1}\right)$}

The lowest part of the Aruküla complex is mainly represented by very fine-grained and fine-grained reddish brown loose sandstones with violet shades, alternating with interbeds of reddish and greenish siltstone, reddish brown clay, more rarely grey or variegated domerite. The thickness of the complex is $15-23 \mathrm{~m}$. Greater thicknesses (also the maximum of $32.3 \mathrm{~m}$ in the Kioma drill core) occur in southeastern Estonia. More significant outcrops are Aruküla caves and exposures at a Tartu cemetery and Viljandi. In its extent this level corresponds roughly to the Viljandi Member established by Viiding in 1981 (Вийдинг et al., 1981; Table 1); therefore it would be reasonable to stick to this name and to distinguish the Viljandi Beds in the lower part of the Aruküla Stage. 
The lower boundary of the Viljandi Beds coincides with the boundary between the Narva and Aruküla stages, which is often hard to establish (Марк \& Тамме, 1964), particularly in the region of the Võrtsjärv Depression. In general, this boundary runs along the lower surface of the first significant uncemented reddish brown sandstone layer lying above the dolomitic siltstone or domerite of the Narva Stage. The topmost part of the Narva Stage often shows a thin greenish grey layer, the overlying sandstone is mostly inequigranular (Fig. 2A). The topmost part of the Viljandi Beds is mainly represented by red-coloured thinbedded siltstones or silty sandstones. The underlying beds are sometimes represented by the first interlayer of variegated lump siltstone.

In the eastern part of the area studied (Slantsy, Verholjane, Petseri, Värska) the Viljandi Beds are dominated by sandstones, in its middle and western parts by silty sandstones and siltstones. The rocks have a microlaminated, often platy and slaty structure, which is particularly well expressed in clays. Sandstones are frequently characterized by cross-bedding. The thickness of the series rarely exceeds $10-15 \mathrm{~cm}$. Inclination is mostly to the south. Characteristic are highly micaceous surfaces and layers rich in clay pebbles occurring especially in the sandstones of eastern sections. The pebbles are rounded, up to $2-3 \mathrm{~cm}$ in size.

The quartz content in rocks is $60-90 \%$. The highest contents (80$90 \%$ ) occur in a belt ranging from the northeastern part of the studied area (Slantsy) up to the town of Valga. The lowest contents $(50-70 \%)$ have been recorded in western Estonia. The amount of feldspar (mostly orthoclase) ranges from 10 to $25 \%$, only rarely reaching $25-32 \%$ (in western Estonia and the Võrtsjärv Depression). Micaceous minerals, above all muscovite, form $3-25 \%$ of the light fraction. The content of the minerals of this group is somewhat higher in western Estonia.

The heavy fraction is dominated by ilmenite $(30-60 \%)$ and the group of transparent allothigenic minerals, whose share is particularly noteworthy in the overlying part of the beds (Fig. 2). The amount of leucoxene is $3-10 \%$. The content of micaceous minerals is quite variable; they are represented primarily by green biotite $(0-91 \%$, usually $10-20 \%)$ and $\mathrm{Fe}$ hydroxides $(2-15 \%$, rarely up to $50 \%)$.

Among heavy transparent allothigenic minerals apatite, garnet, and zircon are the most significant. Important are also tourmaline, staurolite, and rutile. The northwestern province (I, Figs. 1, 3) is dominated by garnet $(30-50 \%)$ with a considerable apatite $(12-27 \%)$ and zircon $(15-43 \%)$ admixture. In the central part of the studied area (province II and the northwestern part of province IV, Fig. 1) the group of heavy transparent allothigenic minerals is dominated by apatite $(20-60 \%)$, particularly in the Vortsjärv Depression. The average contents of zircon $(6-40 \%)$, garnet $(2-30 \%)$, and tourmaline $(11-20 \%)$ are almost equal here. In the West-Estonian province (III, Fig. 1) zircon (18$43 \%)$, apatite $(12-41 \%)$, and garnet $(18-34 \%)$ occur in almost equal amounts. The southeasternmost part of Estonia (southeastern part of province IV, Fig. 1) differs considerably from the other regions. This area is predominated by zircon $(35-60 \%)$ with noteworthy apatite $(10-44 \%)$ and tourmaline $(10-17 \%)$ admixtures. The percentage of garnet is low, ranging from 1 to $13 \%$ (Fig. 3).

Besides the above minerals, the Viljandi Beds have yielded insignificant quantities of monazite, kyanite, corundum, sphene, anatase, brookite, amphiboles, pyroxenes, and epidote. Corundum occurs typically in the northeastern province. In the central and southeastern provinces this group includes also staurolite, which is practically lacking in the sections of the western province, 
As a rule, the lower part of the Viljandi Beds shows a high content of zircon (Fig. 2), northeastern sections zircon and garnet. This regularity is relatively less noticeable in the northern part of the central province, where the share of tourmaline is somewhat higher in these beds.

The group of clay minerals is greatly dominated by hydromicas, which form $90-100 \%$ (on the average $93 \%$ ) of the total. Frequent is chlorite, although it does not exceed $10 \%$ in amount. Kaolinite occurs locally only in southeast Estonian sections; its content reaches $5-10 \%$, in one case $15 \%$ (average $2 \%$ ).

\section{Kureküla Beds $\left(\mathrm{ar}_{2}\right)$}

The middle, almost arenaceous part of the Aruküla Stage is from 20 to $44 \mathrm{~m}$ in thickness. The most important outcrops are Kallaste, Oisu, Paistu, and Tamme. The last is known as a rich fish locality. The complex was named after the village of Kureküla lying near the Tamme outcrops.

Sandstones are highly predominant in the northeastern province of the Kureküla Beds; they alternate with siltstones, in the upper part of the section also with clayey, in some cases with domeritic or dolomitic interbeds. The role of siltstones is somewhat higher in the central and western provinces, where they form $15-25 \%$ of the section. In the southeastern province the share of siltstones is the highest reaching $60 \%$. The number of clay interbeds is also the greatest in the southeast, in the Põlva and Valga sections, where they make up almost $40 \%$. Silty and clayey interbeds occur mostly in the upper part of the complex.

The basal part of the Kureküla Beds is marked by a sandy complex of weakly sorted material, often by a layer of greyish white sandstone. Characteristic is the appearance of interlayers of variegated siltstone. The topmost part of the beds is represented by a thin-bedded complex of sandy-silty, in the southeastern province of sandy-clayey rocks.

Sandstones are reddish brown, often with a yellowish shade, interbedded with yellowish red and pinkish red, in the lower part also with greyish white sandstones. They are mainly fine- and very fine-grained, with the medium $(0.25-0.5 \mathrm{~mm})$ and coarse $(>0.5 \mathrm{~mm})$ fractions not exceeding $10-15 \%$. Characteristic is a cross-bedded structure with the thickness of the series of $10-60 \mathrm{~cm}$, mostly $20-30 \mathrm{~cm}$. Inclination is between 130 and $220^{\circ}$. Weakly cemented sandstones contain predominantly lens-shaped $10-20 \mathrm{~cm}$ thick (sometimes up to $50 \mathrm{~cm}$ ) interbeds of hard yellowish brown conglomeratic sandstone with poikilitic or basal dolomitic cement. These are frequently connected with layers rich in clay pebbles, although such layers may occur also independently. Clay pebbles are reddish brown and greenish grey, rounded, up to $15 \mathrm{~cm}$ in diameter. Reddish brown pebbles often have a thin greenish grey coating. Red sandstone contains rounded, vertical, and irregular pockets of white sandstone that are from a few centimetres up to $50-60 \mathrm{~cm}$ (mostly $10-20 \mathrm{~cm}$ ) in diameter. The presence of $2-5 \mathrm{~cm}$ thick dark brown and grey lenticular interbeds consisting almost only of micaceous minerals is also characteristic. Fe hydroxidic crusts are sometimes recorded in the sandstone.

Siltstones are predominantly variegated-reddish brown and violet grey with interlayers of reddish brown and greenish grey siltstone. Variegated siltstones are unevenly cemented and often break into lumps. Clays are reddish brown, mostly silty.

The rocks of the Kureküla Beds are rich in quartz, its content being $72-92 \%$. Lower quartz contents $(65-80 \%)$ occur in the Võrtsjärv Depression and in the western province. Feldspars, mostly orthoclase, 
form 5-18\%; micaceous minerals, mostly muscovite, $1-18 \%$ of the minerals.

The heavy fraction is mostly composed of ilmenite $(30-60 \%)$ and the group of transparent allothigenic minerals $(20-35 \%)$. The share of leucoxene is between 3 and $14 \%$. The contents of micaceous minerals $(0-50 \%)$ and $\mathrm{Fe}$ hydroxides (usually $2-10 \%$, rarely up to $35 \%$ ) are variable.

The basic transparent allothigenic minerals in the Kureküla Beds are zircon $(18-60 \%)$ and garnet $(10-50 \%$, Fig. 3$)$. As a rule, the zircon content is especially high in the basal part of the section (Fig. 2). Staurolite occurs everywhere, though in the southeastern and western provinces in small amounts.

The most distinguished among the mineralogical provinces is the southeastern province (IV, Figs. 1,3). It is characterized by a high predominance of zircon $(30-74 \%)$, low percentage of garnet $(1-15 \%)$, high mean contents of apatite $(6-24 \%)$ and tourmaline $(10-23 \%)$. The northeastern and central provinces were mineralogically similar in Kureküla Age. In the southern part of province II this level has revealed the maximum amounts of apatite and tourmaline. In the western province the garnet content is somewhat higher. In general, the increased rate of garnet can be traced on a $20 \mathrm{~km}$ wide strip from Verholjane to Abja.

The content of rutile in the Kureküla Beds is everywhere $3-6 \%$; monazite, kyanite, titanite, anatase, amphiboles, and pyroxenes occur in small amounts.

Clay minerals are dominated by the group of hydromicas (mean content $89 \%$ ). Kaolinite occurs in southeastern Estonia, amounting to $10-20 \%$ there, but it is almost missing in the other regions. Chlorite is of very rare occurrence; it is found only in the western province, where it amounts to $10 \%$.

\section{Tarvastu Beds $\left(\mathrm{ar}_{3}\right)$}

The upper beds of the Aruküla Stage are represented by a complicated complex of alternating sandstones, siltstones, and clays. Sandstones are clearly dominating only in the northeastern province. In the central province siltstones often prevail; in the southeastern and western provinces, however, clays are prevalent. Clayey interbeds occur most often in the upper part of the complex. The thickness of the Tarvastu Beds is 20-40 m. Representative outcrops are located at the Mõra Brook near Haaslava and on the shores of the Tarvastu River and Raaga Brook in the vicinity of Tarvastu. The name of this level derives from the latter group of outcrops with the stratotype at the Tarvastu Mill.

The basal part of the Tarvastu Beds is usually marked by a layer of conglomeratic sandstone, that has often the so-called globular structure and lies on the silty or clayey complex of the Kureküla Beds. The upper part of the Tarvastu Beds is represented by a clayey complex or contains clayey interbeds.

The sandstones of the Tarvastu Beds are mostly reddish brown, finegrained, cross-bedded. The series are $20-30 \mathrm{~cm}$, sometimes up to $50 \mathrm{~cm}$ thick. Inclination is $130-180^{\circ}$. A characteristic feature is the occurrence of $5-15 \mathrm{~cm}$ thick interbeds of whitish grey platy sandstones and $3-10$ $\mathrm{cm}$ thick beds of greenish grey platy siltstone. Frequently there occur lens-shaped 2-10 cm thick interbeds of yellowish and violet-grey strongly cemented conglomeratic sandstone; irregular, often vertical pockets of white sandstone up to $12 \mathrm{~cm}$ in diameter; and irregular nodules $(1-5 \mathrm{~cm})$ of highly cemented light sandstone. Locally clay pebbles 
$2-5 \mathrm{~cm}$ in size and Fe hydroxide crusts with a thickness of up to $10 \mathrm{~cm}$ may occur. Strongly cemented sandstones have also displayed caverns.

Fine-laminated greenish grey siltstones occur together with reddish brown and variegated varieties. Clays are reddish brown and variegated, showing reddish brown, greenish grey, violet-grey, and mustard-yellow colours.

The quartz content in the rocks ranges from 58 to $93 \%$. Its rates are higher $(80-93 \%)$ in the southeastern province. The share of feldspars is $6-20 \%$, that of micas ranges from less than $1 \%$ to $30 \%$.

The heavy fraction is dominated by ilmenite, which amounts from 20 to $68 \%$; the content of transparent allothigenic minerals is $12-43 \%$. The percentage of leucoxene is $2-10 \%$, that of $\mathrm{Fe}$ hydroxides $0.3-15 \%$. Pyrite occurs in some levels, its maximum content being $10 \%$.

The group of transparent allothigenic minerals is dominated by zircon and garnet (Figs. 2, 3). The prevalence of zircon is especially notable in the southeastern province, where it forms $40-75 \%$ of the group. In the southeastern province, which widens to the northwest, the content of tourmaline is $8-25 \%$, that of apatite $7-20 \%$, and garnet $0.5-10 \%$. In other provinces the average mineralogical parameters of the Tarvastu Beds are quite similar (Fig. 3). The share of zircon is $16-50 \%$, that of garnet $10-42 \%$, apatite $7-44 \%$, tourmaline $4-20 \%$, and rutile $3-11 \%$. Staurolite occurs everywhere, but its content varies in different provinces: in the northwestern province $5-16 \%$, central province $2-8 \%$, southeastern province $2-12 \%$, western province $0.5-6 \%$. The ratios of minerals vary irregularly in the central province. The belt with the highest garnet content is of a sinuous shape, running in the direction of Slantsy-Verholjane-Kaagvere-Aakre-Valguta.

In the vertical section the amount of zircon is, as a rule, big in basal beds (Fig. 2), while tourmaline-rich levels occur in the upper part of the section.

Clay minerals are dominated by hydromicas with the average percentage of $83 \%$. Kaolinite occurs everywhere as a $10-20 \%$ admixture (average 15\%). Chlorite is found in small amounts, the average being $2 \%$.

\section{COMPARISON WITH SOUTHERN EAST BALTIC}

In Latvia and Lithuania the thickness of the Aruküla Stage is somewhat smaller than in Estonia, ranging from 44 to $77 \mathrm{~m}$. In Latvia the stage has long been treated as an independent unit. In Lithuania it is as a rule considered as the Upnikai Stage including also the Burtnieki Stage. However, also in Lithuania a tendency has emerged to regard the Aruküla Stage as an independent unit (Угинчюс, 1976; Рaškevičius, 1993), which contains three cyclic complexes (V. Narbutas, pers. comm.). On the Latvian territory several subunits have been distinguished: two by Kurš (Куршс, 1975, 1992) and four by Polivko (Поливко, 1977). In the Moscow syneclise the Aruküla Stage corresponds to three units - the Mosolov, the Upper-Chernoyar, and the Lower-Chernoyar stages (Тихомиров, 1967).

In the whole East Baltic area regular occurrence of uneven carbonate cementation, strongly cemented silty-sandy pebbles, hard conglomeratic interbeds, and variegated siltstones has been noted in the upper part of the stage (Куршс, 1975, 1992).

Correlation of lithologically and mineralogically thoroughly studied sections has allowed to distinguish the three levels described above in all of them (Figs, $2 B, 4$ ). The zircon-rich southeastern province 


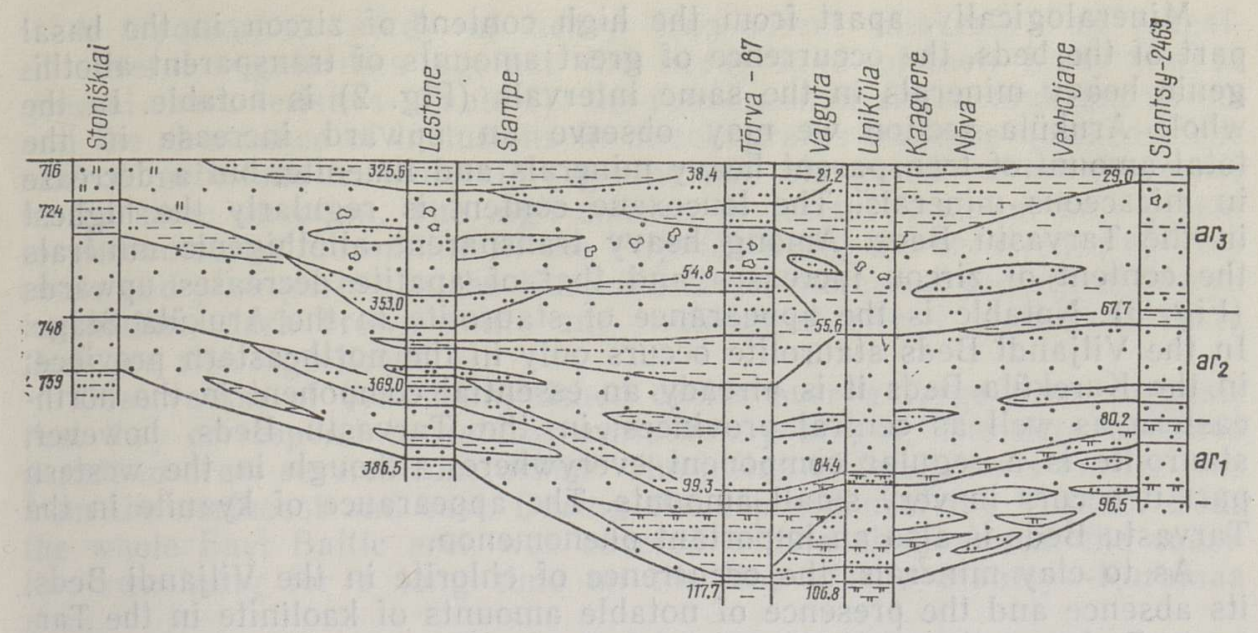

Fig. 4. The geological section of the Aruküla Stage from Slantsy (NE) to Stoniškiai (SW).

The initial data on the Stoniškiai core section by J. Kisnerius (Киснерюс, 1974). For legend see Fig. 2.

established in Estonia continues as a distinct northeast-southwest-directed belt up to Stoniškiai-Nida. This province shows also a considerable kaolinite content. Southeastern Latvia and northeastern Lithuania represent a garnet- and zircon-rich province with a substantial staurolite admixture, most resembling the northeastern province of Estonia (Fig. 3 ). These provinces correspond to various facies of the Devonian basin. During the whole Aruküla time the deepest, most stable part of the marine basin coincided with the southeast Estonia (province IV) - Stoniškiai line.

\section{SUMMARY}

The distinction of the Viljandi, Kureküla, and Tarvastu beds in the Aruküla Stage is mostly based on the cyclic structure of the section. Each unit begins with relatively coarse and less sorted sandstones of a mature mineralogical composition, but ends with a clayey-silty complex (Fig. 2). The Viljandi Beds are generally dominated by very fine sandstones; in their lowermost layer, however, the content of the fine fraction is typically up to $50 \%$. The Kureküla Beds begin usually with a layer of whitish grey or yellowish fine sand that contains a noticeable amount $(3-14 \%)$ of medium-grained sand. The Tarvastu Beds begin with a predominantly conglomeratic layer, often having a structure of the so-called globular sandstone.

Every unit has its own characteristic lithological feature. Siltstones and very fine-grained sandstones of the Viljandi Beds are often platy or slaty fine-bedded. The Kureküla Beds are characterized by irregularly cemented interbeds of variegated siltstones, pockets of white sandstone, lenses of conglomeratic sandstone, and interlayers with big clay pebbles. The Tarvastu Beds contain typically conglomeratic yellowish and violetish interbeds, pebbles of strongly congregationally cemented sandstone, and surfaces and crusts of Fe hydroxide. 
Mineralogically, apart from the high content of zircon in the basal part of the beds, the occurrence of great amounts of transparent allothigenic heavy minerals in the same intervals (Fig. 2) is notable. In the whole Aruküla section we may observe an upward increase in the total amount of transparent heavy minerals and ilmenite, but a decrease in micaceous minerals. The leucoxene content is regularly the highest in the Tarvastu Beds. Among heavy transparent allothigenic minerals the content of zircon increases and that of apatite decreases upwards (Fig. 3). Notable is the appearance of staurolite in the Aruküla Stage. In the Viljandi Beds staurolite occurs only in the northeastern province; in the Kureküla Beds it is already an essential component in the northeastern as well as central provinces; in the Tarvastu Beds, however, staurolite is a regular component everywhere, although in the western part it occurs in very small amounts. The appearance of kyanite in the Tarvastu Beds is also an important phenomenon.

As to clay minerals, the occurrence of chlorite in the Viljandi Beds, its absence and the presence of notable amounts of kaolinite in the Tarvastu Beds are the most significant features.

Percentage of typomorphic varieties of some minerals in their total amounts

\begin{tabular}{l|l|l|l|}
\hline \multirow{2}{*}{ Mineral } & \multicolumn{2}{|c}{ Stratigraphic unit } \\
\cline { 2 - 3 } & $a r_{1} \mid$ & $\mathrm{ar}_{3}$ \\
\hline
\end{tabular}

Zircon

Well-rounded

Elongated

Brown

Yellow

Pink

Zoned

Dirty

Fractured

With inclusions

Tourmaline

Well-rounded

Elongated

Green

Green to pink

Brown

With inclusions

With abundant inclusions

Weathered

\section{6}

Rutile

\section{Elongated}

Dark brown

Brown

Yellow

Grey

Greenish 
A typomorphic study of heavy transparent minerals has revealed several regularities against the background of their fairly similar general characteristics (Table 2): the roundness of zircon and tourmaline and the abundance of inclusions in zircon grains increase upwards. The role of inclusions in tourmaline grains and elongated rutiles decreases in the same direction. The high content of fractured zircon and greento pink-coloured tourmaline in the Viljandi Beds, the occurrence of grey rutile and pink garnet in the Kureküla Beds, increased content of brown tourmaline, dark brown rutile and multiedged zircon in the Tarvastu Beds are also significant.

Observation of the distinguished cycles over a large area suggests that they correspond to natural evolutionary stages. The data obtained permit to draw several conclusions. The influx of terrigenous matter was from the northeast and east. During the deposition of the Viljandi Beds the whole East Baltic area was covered with a shallow sea, the coastline remaining for a long time on the line of the Slantsy-Kuramaa peak.

Beginning with the sedimentation of the Kureküla Beds, the area of Estonia turned into a region of complicated tectonic development, where marine conditions were replaced for a short period by subareal ones. In Kureküla age marine conditions were still strongly predominant. The coastline shifted southeastwards. Fluctuations of the sea level became more complicated in Tarvastu age, probably characterized already by subareal gaps in sedimentation. Here also redeposition of the material from the same area can be recorded.

\section{ACKNOWLEDGEMENTS}

The author expresses her thanks for the criticism of the text to E. Pirrus and D. Kaljo; to A. Noor for linguistic improvements and to

K. Ronk for the figures.

The research was made possible in part by Grant No. 318 from the Estonian Science Foundation.

\section{REFERENCES}

Gross, W. 1940. Uber des Devon der russischen Tafel. - Geol. Rundschau, 31, 2, $7 / 8,525-547$.

Gross, W. 1942. Fischfaunen des baltischen Devons und ihre biostratigraphische Bedeutung. - Korrespondenzbl. Naturf. Riga, 64, 376-436.

Orviku, K. 1946. Tartu linna hüdrogeoloogia. - TRU toimetised, geol. ja geogr., 1, 56.

Paškevičius, J. 1993. Of the Vendian-Devonian stratotypes of Lithuania. Baltic Strat. Ass., Lith. Geol. Inst. Vilnius, 104.

Вийдинг Х. 1965. Некоторые методические вопросы литолого-минералогического анализа песчано-алевритовых пород Прибалтики. - Уч. зап. Тартуск. ун-та, 168. Тр. по геологии, III. Тарту, $5-27$.

Вийдинг Х. 1976. Об интерпретации данных минералогического анализа. - In: Методика и интерпретация результатов минералогических и геохимических исследований. Мокслас, Вильнюс, 53-59.

Вийдинг Х. А., Каяк К. Ф., Марк-Курик Э. Ю., Куршс В. М. 1981. Арукюлаская свита. - In: Девон и карбон Прибалтики. Зинатне, Рига, 112-126.

Киснерюс Ю. Л. 1974. Опорный разрез скважины «Стонишкяй» Литовской ССР. Периодика, Вильнюс. 
Клеесмент А. 1976. О принципах корреляции разрезов на основе минералогических показателей (на примере палеозойских терригенных отложений Прибалтики). - In: Методика и интерпретация результатов минералогических и геохимических исследований. Мокслас, Вильнюс, 44-52.

Куршс В. М. 1975. Литология и полезные ископаемые терригенного девона Главного поля. Зинатне, Рига.

Куршс В. М. 1992. Девонское терригенное осадконакопление на Главном девонском поле. Зинатне, Рига.

Марк Э. Ю. 1958. О некоторых вопросах стратиграфической номенклатуры девона северо-запада Главного поля. - Изв. АН ЭССР. Сер. техн. и физ.-матем. наук, VII, 4, 348-349.

Марк Э. Ю., Тамме А.-Л. Э. 1964. О границе наровского и арукюлаского горизонтов в Эстонской ССР. - In: Вопросы стратиграфии и палеогеографии девона Прибалтики. Минтис, Вильнюс, $67-73$.

Поливко И. А. 1977. Палеогеография и палеотектоника раннего и среднего девона Средней Прибалтики. Зинатне, Рига.

Рухин Л. Б. 1946. Стратиграфия песчаной толщи среднего девона Лужского и Оредежского районов Ленинградской области. - Науч. бюл. Ленингр. ун-та, $10,23-25$.

Тихомиров С. В. 1967. Этапы осадконакопления девона Русской платформы. Недра, Москва.

Угинчюс А. 1976. Минералогические критерии расчленения и корреляции разрезов упникяйской и швянтойской свит $\left(\mathrm{D}_{2-3}\right)$. - In: Методика и интерпретация результатов минералогических и геохимических исследований. Мокслас, Вильнюс, 109-115.

\title{
ARUKULA LADEME LIIGESTAMINE LITOLOOGILIS- MINERALOOGILISTE KRITEERIUMIDE ALUSEL
}

\author{
Anne KLEESMENT
}

Artiklis on põhjendatud Aruküla lademe läbilõike kolmikjaotust ning esitatud püstitatud Viljandi, Kureküla ja Tarvastu kihtide väljaeraldamise kriteeriumid ning nende litoloogilis-mineraloogilised tunnused. On antud nende kihtide korrelatsioon Baltikumi regioonis.

\section{РАСЧЛЕНЕНИЕ АРУКЮЛАСКОГО ГОРИЗОНТА НА ОСНОВЕ ЛИТОЛОГО-МИНЕРАЛОГИЧЕСКИХ КРИТЕРИЕВ}

\section{Анне КЛЕЕСМЕНТ}

Приведены обоснования в пользу расчленения арукюлаского разреза на три самостоятельные стратиграфические единицы - вильяндискую, курекюласкую и тарвастускую пачки. Даны литолого-минералогические характеристики пачек и прослежено их распространение в Прибалтийском регионе. 